\title{
EFFECTUAL CALL OR CAUSAL EFFECT? SUMMONS, SOVEREIGNTY AND SUPERVENIENT GRACE
}

\author{
Kevin J. Vanhoozer
}

\begin{abstract}
Summary
Classical theism is in danger of being overthrown by the current revolution in theological paradigms. The doctrine of the effectual call affords a good case study of the broader God/world relation: if God's call and divine action in general are interventions, then grace appears ultimately to be a matter of efficient causalityan impersonal relation. Panentheists argue that God need not intervene in the world because the world is in God and, therefore, is open to his general call. On the panentheistic analogy, God is to the world as the mind is to the brain, and divine grace, like the mind, does not intervene but 'supervenes' on the world, God's body. It is not clear, however, whether God's personal agency can be preserved in this model. Rethinking the doctrine of the effectual call in terms of 'speech acts' suggests a new picture for the God/world relation, where the Spirit 'advenes' on the Word to bring about not an impersonal but a uniquely personal effect: understanding.
\end{abstract}

\section{Introduction: theism in crisis}

\section{Two types of systematic theology}

Assumptions about the way God relates to the world lie behind every doctrine in systematic theology. The decision one makes as to how to conceive this relation is arguably the single most important factor in shaping one's theology. Paul Tillich spoke of two types of philosophy of religion to distinguish two ways of approaching God: by way of meeting a stranger, and by way of overcoming estrangement. ${ }^{1}$ The first, or cosmological way, conceives of God as a personal being who can interact (or not)

1P. Tillich, 'Two Types of Philosophy of Religion', in Theology and Culture (Oxford: OUP, 1959) 10-29. 
with the world. The second, or ontological way, conceives of the world as always/already existing 'in' God.

Christian theologians are today faced with a similar choice between 'theism' and 'panentheism'. It may be only a slight exaggeration to say that we are in the midst of a paradigm revolution, but it is clear that the traditional doctrine of God (i.e., classical theism) is in crisis. Theologians of various denominational stripes, liberal and conservative, faced with the choice for or against classical theism, are increasingly abandoning ship. ${ }^{2}$

Such is the broad canvas on which I wish to apply some initial brushwork, though for the most part I shall confine my attention to a small corner only. While I am interested in these rival pictures of the God/world relation, my focus will be on saving grace. I shall therefore examine that Benjamin of theological concepts, the Reformed doctrine of the effectual call, keeping in mind the ways in which this doctrine is coloured by, and perhaps itself affects, the broader God/world relation.

\section{The sovereign stranger:}

\section{Some problems with theistic transcendence}

Three criticisms are commonly applied to what Tillich describes as the first way of approaching God, the way of meeting a stranger: it is unbiblical; it is blasphemous; it is unscientific.

Clark Pinnock, for instance, claims that classical theism drank too deeply from the poisoned wells of Greek philosophy. Consequently, its conception of God as immutable omnipotence is a far cry from the biblical picture of a dynamic, loving God. ${ }^{3}$ Karl Barth renders a similarly harsh judgement on Reformed orthodoxy: 'The dogmatics of these centuries had already been too closely bound up with a form not taken from the thing itself

\footnotetext{
2It sometimes seems that the only people interested in classical theism these days are analytic philosophers of religion rather than systematicians. ${ }^{3} \mathrm{C}$. Pinnock: 'Above all, God is love, and therefore expresses his power, not by having to control everything like an oriental despot, but by giving humanity salvation and eternal life under the conditions of mutuality' ('Introduction', The Grace of God, the Will of Man [Grand Rapids: Zondervan, 1989] x-xi).
} 
but from contemporary philosophies.' 4 The fundamental problem with classical theism, Pinnock believes, is that it wrongly conceives the God/world relation in deterministic, impersonal terms.

Secondly, Tillich argues that theism, because it conceives of God as the supreme being, ends up in a kind of idolatry, identifying God as part of the furniture of the cosmos and believing that it can conceive God. That God is a 'sovereign' being, whose decrees determine everything whatsoever that comes to pass, only complicates things. If God supernaturally intervenes in the world, then why is there suffering and evil? Feminist and process theologians similarly accuse theism's monarchical picture of God of providing a tacit endorsement to patriarchy and social oppression.

For many contemporary theologians, however, probably the most compelling reason to abandon the theistic paradigm is its apparent conflict with what modern science has taught us about our world: 'it is probably safe to say that the whole of Christian doctrine as received from tradition is built on the assumption of supernatural causal intervention.' 5 Yet few modern theologians are happy to construe the God/world relation in terms of divine intervention. Schleiermacher influenced a whole theological tradition when he judged it a mistake to see God as overriding or supplementing natural causes, for to think of God in terms of exercising efficient causality is to think of God in terms appropriate to creatures: 'It can never be necessary in the interest of religion so to interpret a fact that its dependence on God absolutely excludes its being conditioned by the system of Nature.' 6

Summing up these three problems, we see that the main complaint against classic theism is that it pictures the God/world relation in terms of efficient causality. Indeed, the theology of the so-called Reformed scholastics of the

${ }^{4} \mathrm{~K}$. Barth, 'Introduction' to Heinrich Heppe, Reformed Dogmatics (Grand Rapids: Baker, 1978) vi.

5J. Hopper, Understanding Modern Theology II: Reinterpreting Christian Faith for Changing Worlds (Philadelphia: Fortress, 1987) 34).

6F. Schleiermacher, The Christian Faith (Edinburgh: T. \& T. Clark, 1928) 178. 
seventeenth century has been described as 'causal analysis'. Is it indeed the case that the question 'how do sinners get grace' requires a causal explanation? It is precisely this way of construing the God/world relation that is today being challenged. Hence our problem: if God does not intervene in nature, then what are to make of the effectual call?

\section{Why the effectual call?}

Why discuss the challenge to theism under the rubric of the effectual call? Why think that the effectual call affords us an interesting way into, and through, debates about the way to conceive the God/world relation?

First, because it represents a microcosm of the fundamental problem, namely, the way in which God relates to the human world. As such, it affords an interesting test case by which to explore the respective merits of theism and panentheism. ${ }^{7}$

Second, because it focuses our attention on the particular problem of how divine grace brings about change in the world. In other words, it allows us to examine the Reformed picture of how God relates to the world at what many consider its most contentious, and most vulnerable, point: the relation of grace and human freedom.

And lastly, because it provides a vital clue to a better way forward for thinking the God/world relation in general. For if we can understand how God can work in the human person without violating the laws of human nature, perhaps we will see better how God acts in the wider world without violating the laws of its nature. I believe that the notions of divine action in general and divine calling in particular may be mutually enriched when they are thought together.

\footnotetext{
${ }^{7}$ Whereas D.M. Baillie saw the Incarnation as the paradigm instance of how believers receive grace, I submit the effectual call as a better model. The effectual call is thus a microcosm of the paradox of grace.
} 


\section{Calling: the nature of the doctrine}

\section{Calvin}

Calvin places his discussion of God's call in Book III of the Institutes 'The way we receive the grace of Christ', immediately after his treatment of the doctrine of election. Indeed, the call 'confirms', 'attests' and 'makes manifest' God's election. Following Paul's order in Romans 8:29-30, Calvin insists that God first elects, then calls, then justifies: 'And those whom he predestined he also called; and those whom he called he also justified' (Rom. 8:30). Calvin makes the further point that 'the manner of the call itself clearly indicates that it depends on grace alone' (III.xxiv.2). What is this manner? For Calvin the call consists in the preaching of the Word and the illumination of the Spirit. This explains Calvin's later statement that there are two kinds of call: the general call associated with the 'outward preaching' of the word on the one hand, and the special, inward call which is given to the elect only which, thanks to the Spirit, 'causes the preached Word to dwell in their hearts' (III.xxiv.8). 'Many are called but few are chosen' (Mt. 22:14). ${ }^{8}$

\section{Seventeenth-century Reformed treatments}

By the seventeenth century, the effectual call had gained privileged status in the ordo salutis, for the call effects one's union with Christ and is the beginning from which all other blessings flow. Vocatio is the Act of God by which through the preaching of the Word and the power of the $\mathrm{H}$. Spirit He brings man from the state of sin to the state of grace'. 9 The effectual call takes place 'over and above' the outward call by the inward power of the almighty Spirit. At the same time, the word by which the Spirit effects calling 'is the same word by which

${ }^{8}$ Calvin adopts a biblical metaphor (calling) to guide his thinking about the way we receive grace. Yet he can also speak the language of the philosopher. Indeed, he applies Aristotle's analysis of causation to the biblical teaching about salvation and argues that the efficient cause of our justification is the love of God the Father, the material cause the obedience of Christ, the instrumental cause the Spirit's illumination (faith), and the final cause the glory of God's generosity (III.xiv.21).

${ }^{9} \mathrm{H}$. Heppe, Reformed Dogmatics, 510. 
God's call to grace is outwardly proclaimed'.10 The internal call is virtually indistinguishable from regeneration: 'Calling is therefore the act of the $\mathrm{H}$. Spirit, by which...He creates a new man... The direct effect of such a calling is thus the regeneration of human nature.' 11

\section{Twentieth-century Reformed treatments}

Not much has changed in three centuries with regard to Reformed treatments of the effectual call. Three points in particular, however, deserve special mention. (1) The effectual call is a divine act. The call represents the temporal execution of God's eternal purpose. ${ }^{12}$ Hence it is something that enters into human history. ${ }^{13}$ (2) The effectual call is virtually indistinguishable from regeneration.14 The call is creative, or recreative. 'God's call to salvation is causative and effectual'.15 Only God can bring about the radical change needed to reorient and renew fallen persons dead in their sins to life in covenant fellowship with God. In his conversation with Nicodemus, Jesus states that no one can enter the kingdom of heaven unless he is 'born of...the Spirit' (Jn. 3:5). (3) The effectual call is 'grounded' in the evangelical call. The internal call is an 'act of divine power, mediated

10 Ibid., 518.

11 Ibid.

12For a more extended treatment of biblical terms for calling, see B. Demarest, The Cross and Salvation (Wheaton, IL: Crossway, 1997) 216-18. J. Murray argues that most New Testament references to 'call' and 'calling' pertain not to the universal call of the gospel but to the effectual call that unites to Christ: 'Calling in an act of God and of God alone' (Murray, Redemption Accomplished and Applied ([Grand Rapids: Eerdmans, 1955] 89).

${ }^{13}$ To be precise, it is a sovereign act of God the Father 'who is the specific agent in the effectual call' (Murray, Redemption Accomplished, 89). A.A. Hoekema agrees, defining effectual calling as 'that sovereign action of God through his Holy Spirit whereby he enables the hearer of the gospel call to respond to his summons with repentance, faith, and obedience' (Saved by Grace [Grand Rapids: Eerdmans, 1989] 86).

${ }^{14}$ So Strong, Bavinck, Hoekema, and most seventeenth-century Reformed theology. L. Berkhof, however, prefers to say that effectual calling follows regeneration (Systematic Theology [Edinburgh: Banner of Truth Trust, 1958] 471) and Murray that effectual calling precedes regeneration (Redemption, $115,119-20)$.

15Demarest, The Cross and Salvation, 217. 
through the proclaimed Word'.16 What follows in the later sections of this paper is an attempt to clarify the precise relation between the evangelical call-Gospel preaching-and the effectual call.

\section{A causal effect? the problem of divine sovereignty and human responsibility}

Is the concept of causality an aid to Christian theology or a Trojan horse? Can we say of this concept what has been said of Aquinas's appropriation of Aristotle in general, that 'The water of philosophy...has been changed into the wine of theology'?17

\section{An objection: the effectual call is an impersonal cause}

A cause is 'an exertion of energy that produces a change'.18 The kind of causal effect wrought by the effectual call is nothing less than a 'change of heart'. If the human response is an effect of the call, does it not follow that God relates to human persons in an impersonal way? If the human being is both creature and person, dependent on God for his being yet able to make responsible decisions, why attribute the effectual call to God alone? Moreover, given the theistic understanding of divine transcendence, must not any divine action be an intervention from 'outside' the spatio-temporal causal network?

Is it indeed fair to see the effectual call as a causal effect? Is God related to the world as a cause is related to its effect? Is saving grace an impersonal force? Aquinas applied Aristotle's conceptual apparatus, used in the Physics to examine natural processes, to the moral and psychological processes of human freedom. For Aquinas, an effect is simply a matter of the nature of its cause playing itself out: 'No being can act beyond the limits of its specific nature, since the cause must always be

16 Ibid., 221.

17Cited in B. Davies, The Thought of Thomas Aquinas (Oxford: Clarendon Press, 1992) 11.

${ }^{18}$ A. Strong, Systematic Theology (Valley Forge, PA: Judson Press, 1907) 815. 
of a higher potency than its effect.' 19 Hence grace is 'the work of God in human beings raising them above their human nature to the point where they become sharers in the divine nature'.20 Aquinas here invokes the Aristotelian doctrine of the Prime Mover. 'It is in fact movement-change and instantiationfrom which St Thomas starts here in order to locate grace in a metaphysical pattern.'21 Grace is a supernatural cause, over and above human nature, that produces a supernatural effect.

Does grace contravene human freedom? No, grace enables human freedom to do what it otherwise could not. My actions are free if nothing in the world is acting on me so as to make me perform them. For Aquinas, to be free means 'not to be under the influence of some other creature, it is to be independent of other bits of the universe; it is not and could not mean to be independent of God'.22 Aquinas, however, does speak of grace in terms of assistance as well. ${ }^{23}$ In this case, grace acts on the soul 'not in the manner of an efficient cause but in the manner of a formal cause; so whiteness makes something white and justice makes someone just' ${ }^{24}$

Reformed statements concerning saving grace continued to use the language and conceptuality of causality. They reclaimed the Augustinian theme of the irresistibility of saving grace in order to refute synergism, the suggestion that one's coming to saving faith is an event in which God and humans cooperate. Yet monergism suggests that God's will is both a necessary and a sufficient cause for moving the human will: 'In itself calling is always effectual, although it is not so in

${ }^{19}$ Thomas Aquinas, Summa Theologiae, Ia2ae. 112, 1. Note: the newer scientific picture of the world as composed of hierarchical levels of ascending complexity contests this picture.

${ }^{20}$ Davies, The Thought of Thomas Aquinas, 264.

${ }^{21}$ C. Ernst, 'Introduction', to Summa Theologiae vol. 30.

22So H. McCabe, cited in Davies, Thought of Thomas Aquinas, 177.

${ }^{23}$ Aquinas also views the grace of regeneration as an infusion of the theological virtues that transforms the source of one's actions-one's very being-and hence one's behaviour.

24 Summa Theologiae, Ia2ae, 110, 2. 
those who are perishing, as the sun is effective by his light in itself, although it by no means illumines the blind.'25

According to the Westminster Confession of Faith (X.2), effectual calling includes regeneration, a change in the 'heart', in the very source of our motivation and dispositions. In Berkhof's words: 'There is a sense in which calling and regeneration are related as cause and effect.' 26 Moreover, regeneration takes place 'below consciousness'; Hoekema, for instance, locates one's change of heart in the subconscious. ${ }^{27}$ This is problematic because it questions the necessity of the Word, the external call, and casts doubt on whether grace works with human nature rather than against it.

If the human response were what made the call effectual, then the call would be no more than an invitation that lacked inherent efficacy. In order to ascribe salvation wholly to God, therefore, Reformed theologians insisted that faith is 'not the "cause" but the direct "effect of regeneration", and is 'produced by effectual calling or regeneration.'28 Preaching is the instrumental cause of faith, but only when conjoined with the efficient causality of the Spirit. Indeed, conversion involves two kinds of cause: moral and 'physical'.$^{29}$ By physical, I think the dogmaticians meant to capture what, for instance, Acts 16:14 says about Lydia: 'The Lord opened her heart to give heed what was said by Paul'. Bruce Demarest comments that 'The opening of Lydia's heart by the power of God was the efficient cause of her coming to Christ'. ${ }^{30}$ Some of the language used in earlier dogmatics to describe the call does suggest a certain coercion, even violence-a contravening of human freedom.

${ }^{25}$ Heppe, Reformed Dogmatics, 517. The term 'irresistible' is unfortunate, as even Reformed theologians have noted (e.g., A.A. Hodge, Outlines of Theology [Grand Rapids: Zondervan, 1972] 452). Grace can be resisted, but ultimately God's call will be efficacious, that is, it 'accomplishes the purpose for which it has been sent' (Isa. 55:11).

26Berkhof, Systematic Theology, 470.

27Hoekema, Saved by Grace, 104.

${ }^{28}$ Heppe, Reformed Dogmatics, 527.

${ }^{29}$ Reformed theologians insist, against the Socinians, that conversion is more than a moral persuasion.

30Demarest, The Cross and Salvation, 223. 
Heidegger, for instance, says the Word not only opens but 'attacks' hearts, irrevocably changing them in the process.

Other theologians reject the very idea of an effectual call as 'sub-Christian'. The authors of The Openness of God, for example, contend that the traditional picture of the God/world relation is deficient in several ways. 'God's relation to the world...is one of mastery and control'.31 God remains 'essentially unaffected' by cosmic events and human responses; hence there is no genuine dialogue between God and human beings. 32 It follows for these authors that a God who effectually calls cannot really love the world, for love is a matter, they say, of mutual, reciprocal, and non-coercive relations. Theism's root metaphor of God as Prime Mover of the world and the will is ultimately incompatible with the biblical picture of a God who covenants with humanity. Emil Brunner's comment on Calvin's view of regeneration sums up the objection: 'the personal relation between God and Man became a causal relation: God the cause, faith the effect'. 33

\section{An alternative: a universal, potentially effectual call, or prevenient grace}

There is considerable dissent, even from evangelicals, to the notion of God's intervening grace and supernatural causality. How, then, do non-Reformed evangelicals and contemporary non-evangelical theologians understand the relation of God's grace to humanity? ${ }^{34}$

${ }^{31}$ R. Rice, 'Biblical Support for a New Perspective', in C. Pinnock et al. (eds.), The Openness of God (Downers Grove: InterVarsity Press, 1994) 11.

${ }^{32}$ Furthermore, the suggestion that grace is opposed to or separate from nature has been responsible for the loss of the sense of the divine in nature; supernaturalism, ironically, has led to secularisation. So Moltmann: "The more transcendent the conception of God became, the more immanent were the terms in which the world was interpreted. Through the monotheism of the absolute subject, God was increasingly stripped of his connection with the world, and the world was increasingly secularised' (God in Creation [San Franciso: Harper \& Row, 1985] 1). I acknowledge that thinking of God in terms of causality may have done so, but I believe the emphasis on God as a communicative agent does not.

${ }^{33}$ Brunner, Christian Doctrine of God, 315.

${ }^{34} \mathrm{I}$ am aware that classical Arminians were also classical theists. It is possible, in other words, to be a theist and to hold to prevenient grace. 
For so-called 'free-will' theists who hold to the open view of God, God reacts and interacts with human beings in a way that respects creaturely autonomy. ${ }^{35}$ For these theologians, there is only one kind of grace, one kind of call, and one kind of way in which God is related to the world. God exerts a constant attractive force on the soul-a kind of divine gravity. This universal call comes through a variety of media: the creation itself, conscience, as well as proclamation about Christ. Grace is therefore 'prevenient': that which 'comes before' a person's ability to repent and believe.

On this view, God's call offers the possibility of salvation (salvation potential) to every human being. ${ }^{36}$ Sufficient grace becomes efficient, that is, only when the sinner cooperates with and improves it. 37 As one cooperates, the potential of salvation is actualised and becomes, for that person, a reality. In short, it is the human response-an exercise of free will-that makes the sufficient grace of God common to all efficient in the case of an individual. In Pinnock's words: 'God's grace may be genuinely extended to people, but unless it meets the response of faith...it has no saving effect.' 38 Of course, to say that God's call is conditionally effectual is tantamount to saying that it is intrinsically ineffectual. To put the point more

However, I have not been able to do justice either to Aquinas or to classical Arminianism in the scope of this essay. My argument about the general trend in contemporary theology towards panentheism, however, is unaffected by this omission.

${ }^{35}$ See Pinnock, 'From Augustine to Arminius: A Pilgrimage in Theology', in The Grace of God, the Will of Man, 27.

${ }^{36}$ The notion of universal prevenience signals the democratisation of saving grace which is assumed by most non-Reformed theologians.

${ }^{37}$ 'Grace may be judged to have of itself sufficient power to produce consent in the human will, but because this power is partial, it cannot go out in act without the cooperation of the free human will, and hence, that it may have its effect, it depends on free-will' (cited in Hodge, Outlines of Theology, 455).

${ }^{38}$ C. Pinnock (ed.), Grace Unlimited (Minneapolis: Bethany Publishers, 1975) 15. Note: the title signals the authors' belief that God's grace is unlimited in scope. It does not, however, appear to be unlimited in power. The only way to have grace unlimited both with regard to scope and with regard to power would be to opt for universalism, in which case all humans would be effectually called. 
positively: God's grace is 'non-manipulative and noncoercive'. ${ }^{39}$

Was something like the above also the classical consensus of the ecumenical councils and teachers of the first five centuries? To summarise Thomas Oden's reading of the ecumenical consensus: those who cooperate with the prevenient grace that is always-already there will find that grace becomes effective. Grace cooperates with human freedom and God elects those who respond to the evangelical call.40 'Grace is working so as to elicit my energetic responsiveness, while my hard work is being enabled by grace...The ecumenical consensus has held closely together the freedom of the will and the efficacy of grace.'41

If Oden is correct, we can squeeze even process theology into the ecumenical consensus! Indeed, process theologians have hardened the notion of the evangelical call into a metaphysical principle. Here we return to the second of Tillich's two types, to God as the ground of our being from whom, mysteriously, we have become alienated.

Tillich, Schleiermacher and many other modern theologians agree that God is the one to whom we are always/already related. Schleiermacher, for instance, thought of God as that upon which humans feel themselves 'absolutely dependent', though he was wary of thinking of God's relation to the world in terms of supernatural causality. God is not a being alongside other beings, but an energy that is constantly being experienced to sustain us on our way, whether or not we are conscious of that fact: 'all divine grace is always

${ }^{39} \mathrm{Ibid}$. As Pinnock elsewhere puts it: 'We believe that God not only acts but also reacts' (The Grace of God, the Will of Man, $\mathrm{x}$ ).

${ }^{40} \mathrm{~T}$. Oden, The Transforming Power of God's Grace (Nashville: Abingdon, 1993). Oden explains the difference between the many who are 'called' and the few who are 'chosen' in terms of God's antecedent and consequent will: 'The consequent will of God to save offers the same divine grace as the antecedent. There is only one difference-God's redemptive will is consequent to, or follows upon, human responsiveness' (89).

41 Ibid., 97, 113. Oden writes: 'That the synergy of grace and freedom became the consensual teaching of the believing church is clear from the Third Ecumenical Council' (98). 
prevenient.' 42 For much modern theology, then, prevenient grace has become a matter of ontology.

Process theology represents what is perhaps the logical conclusion of the way in which many non-Reformed theologians now construe the God/world relation. God is a creative participant in the course of world history, the leader of a cosmic community who seeks to persuade beings to choose the good, namely, that which leads to greater self-realisation. Divine transcendence is understood as God's ability to relate to everything that happens. God is not the ruler of the universe but its wooer, working not with causal power but with the power of love and persuasion. The course of history thus takes the shape of a dialogue between God and the world. God and the world come together to converse, to 'enjoy' one another. 43 The way God works with the world, that is, is by convening a cosmic conversation. Grace, we may say, is therefore convenient, achieving its effects not causally, but as it were, conversationally. 44

Moltmann similarly takes issue with the traditional dualities. 45 If God is immanent to the world and if the world is immanent to God, then we 'have to stop thinking in terms of causes at all'. ${ }^{46}$ We must no longer think in terms of one-way relationships such as 'causing', 'making', and 'determining' but in terms of reciprocal relationships like 'indwelling', 'participating', and 'accompanying' ${ }^{47}$

42Schleiermacher, Christian Faith, 485, n. 2.

${ }^{43}$ See Cobb, Introduction to Process Theology, 56.

${ }^{44}$ D.R. Griffin, 'Relativism, Divine Causation, and Biblical Theology', in O.C. Thomas (ed.), God's Activity in the World (Chico, CA: Scholars Press, 1983) 132.

${ }^{45}$ For example, creation/redemption, natural/supernatural, and the dualistic principle upon which they were constructed, namely, that grace perfects nature. He proposes a new principle-grace prepares nature for eternal glory-and suggests that both Christ and the cosmos are moving towards a messianic goal in the power of the Spirit (God in Creation, 9).

46Ibid., 14.

${ }^{47}$ The God-world relation, in other words, reflects the trinitarian relationships of mutual interpenetration and perichoresis. Moltmann writes: "The Trinitarian concept of creation integrates the elements of truth in monotheism and pantheism. In the panentheistic view, God, having created the world, also dwells in it, and conversely the world which he has 


\section{The panentheistic mind-body analogy and 'supervenient' grace}

Tillich, process theologians, Moltmann and others are all riding the panentheistic bandwagon. What is panentheism and why are so many people saying such nice things about it?

\section{The theological concept of panentheism}

Panentheism holds that the world is in some sense in God, though God exceeds the world. This is a novel solution to the problem of how to 'make room' in the material world for God-namely, by making room in God! To speak of God the Creator implies not a hard and fast distinction between God and the world but rather a recognition of 'the presence of God in the world and the presence of the world in God'.48 Panentheism sits nicely with the notion of continuous creation-the idea that God has established processes in nature that bring about God's purposes over time. It is not as though God has to intervene in the world 'from outside' the world, then, but rather that the 'processes revealed by the sciences are themselves God acting as Creator' ${ }^{49}$

\section{The philosophical concept of supervenience}

Panentheism overturns not only the traditional God/world relation but also the way in which Reformed theology has conceived the relation of nature and grace. Can we reclaim and restate the doctrine of the effectual call or ought we abandon it? I did not find much advance on seventeenth-century treatments of the doctrine in my literature review. However, in the rest of this paper I will explore two new things that might be said about the effectual call, in each case relying upon a fairly recent philosophical concept: (1) the effectual call supervenes on the external call; (2) the effectual call is a speech act with a unique communicative force. The challenge, we may recall, is to avoid

created exists in him' (God in Creation, 98). In the constructive portion of this article, I attempt a Trinitarian interpretation of the effectual call.

48Moltmann, God in Creation, 13; cf. 98, 103.

${ }^{49}$ A. Peacocke, Theology for a Scientific Age (2nd ed., enlarged; Minneapolis: Fortress, 1993) 176. 
reducing God to a mere physical cause, on the one hand, or to an ineffectual influence, on the other.

'Interpretation', in the words of Paul Ricoeur, 'is the work of concepts'. As we have seen, classical theism pressed the concept of cause into theological service. Today there is an intriguing new concept that heralds a new chapter in the dialogue between theology and science. The term 'supervene' appears in Dr. Johnson's Dictionary of 1775 with the meaning of 'to come as an extraneous addition'. The etymology of the term might lead one to suspect that supervenience-'coming from above'-is a fitting concept with which to explain God's supernatural agency. In fact, the contemporary use of the term has nothing to do with coming from above.

Philosophers use the concept of supervenience to give naturalistic but non-reductionistic accounts of moral and mental phenomena. 50 The main idea involves a certain relation between two sets of properties that nevertheless describe the same entity or event. R.M. Hare introduced supervenience into modern moral philosophy in 1952. Suppose that we say 'St Francis was a good man'. On this Hare writes:

It is logically impossible to say this and to maintain at the same time that there might have been another man placed exactly in the same circumstances as St. Francis, and who behaved in exactly the same way, but who differed from St. Francis in this respect only, that he was not a good man.51

Supervenience is the relation between the 'good', on the one hand, and certain patterns of behaviour and character traits, on the other. Hare's point is that there is a necessary correlation between moral properties and non-moral properties. This is the core idea of supervenience: 'No differences in A properties without differences in B properties', where A stands for moral properties like goodness and B stands for non-moral properties (e.g., actions like feeding animals or giving away money). St Francis' goodness depends on his feeding animals and his

50See J. Divers, 'Recent work: Supervenience', in Philosophical Books (1998) 81-91; E.E. Savellos and U.D. Yançin (eds.), Supervenience: New Essays (Cambridge: CUP, 1995).

51R.M. Hare, The Language of Morals (Oxford: Clarenden Press, 1952). 
poverty but it cannot be reduced to these things. Being poor, after all, is not the same as being good.

Supervenience really comes into its own, however, in the philosophy of mind. Mental properties such as consciousness supervene on physical properties such as brain states. Thoughts depend on neural firings and other subvenient physical events but they are not identical to these physical events nor can they be explained in terms of brain states alone. Supervenient properties, that is, cannot be explained in terms of lower level, subvenient properties.52 It is this apparent irreducibility of the mental to the physical that distinguishes the supervenience relation from that, say, of causality. The relation between physical and mental events is not causal precisely because, as Aquinas rightly noted, an effect (consciousness) cannot be greater than its cause (neural firing). Supervenience is more like a part-whole relation, where the whole is greater than the sum of its parts. 53

Jaegwon Kim, an analytic philosopher who has written on the concept more than anyone else, suggests that supervenience resembles the doctrine of emergence, popular among early twentieth-century supporters of evolution:

when basic physiochemical processes achieve a certain level of complexity of an appropriate kind, genuinely novel characteristics, such as mentality, appear as 'emergent' qualities. ${ }^{54}$

\footnotetext{
52J. Kim, an analytic philosopher and one of the leading proponents of the concept, puts it this way: 'whether something exists, or what properties it has, is dependent on, or determined by, what other things exist and what kinds of things they are' ('Concepts of Supervenience', in Supervenience and Mind [Cambridge: CUP, 1993] 53).

${ }^{53}$ Note that supervenience is a topic-neutral concept that has applications in fields as diverse as morals and physics. An aesthetic example: the beauty of music supervenes on a sequence of sounds, yet we would be unwilling to identify or reduce aesthetics (and the notion of beauty) to physics and the level of sound waves.

${ }^{54} \mathrm{Kim}$, 'Supervenience as a Philosophical Concept', in Supervenience and Mind, 134. Cf. Kim, "Downward Causation' in Emergentism and Nonreductive Physicalism', in A. Berckermann, H. Flohr and J. Kim (eds.), Emergence or Reduction? (Berlin: De Gruyter, 1992).
} 
The cell, for instance, is an emergent phenomenon, a distinct entity in the world with its own science (biochemistry), even though it is composed out of smaller atomic units. Yet one cannot explain the behaviour of a cell in terms of the laws of physics. Similarly, water, at the microphysical level, is composed of the basic particles and atoms of which matter is composed. At the molecular level of $\mathrm{H}_{2} \mathrm{O}$, however, we discover properties such as 'wetness' and 'power to dissolve sugar'. At still higher levels, and under the appropriate conditions, we discover that water has the property of admitting one into the Christian church. Or, to take an example from biblical scholarship (supervenience recognised no disciplinary bounds!): the Christian canon emerges from (or supervenes on) the particular texts that comprise the Old and New Testaments. And though canonical meaning depends on these texts, it cannot be reduced to or explained in terms of individual books. On the contrary, canonical criticism is a science of its own, with its own set of exegetical and explanatory tools.

\section{God's call to the world and the causal joint:}

\section{The mind-body analogy}

How, though, can the concept of supervenience help theologians conceive the God/world relation? The 'panentheistic analogy' asks us to think of God as a person like us, to see a parallel between our action in our bodies and God's action in the world. In particular, it asks us to think of the world as God's body and of God as the mind or soul of the world. 55 As mental activity supervenes on physical processes, so divine action supervenes on the processes of nature.

Interestingly, Heinrich Heppe compares the calling of the elect to the union of soul and body. 56 There is thus orthodox precedent (of sorts) for my appeal to the mind-body analogy. And there is of course biblical precedent in the picture of the

${ }^{55}$ According to Clayton, 'It now seems that this analogy represents one significant argument in favour of panentheism' (God and Contemporary Science [Edinburgh: EUP, 1997] 242).

56Heppe, Reformed Dogmatics, 511. 'By regeneration moreover new life is put into them (the elect), as the result of gracious union with God and His Spirit. What soul is to body, God is to the soul' (519). 
church as the 'body' of Christ, conjoined to the 'spirit' of Christ (1 Cor. 12:13). And as we have seen, the effectual call itself involves two sets of properties, the 'external' and the 'internal': 'There is strictly one calling, but its cause and medium is twofold: instrumental, man preaching the word outwardly; principal, the $\mathrm{H}$. Spirit writing it inwardly in the heart. ${ }^{\prime 57}$ Is it correct to construe this relation in terms of supervenience? Is the mind-body analogy the best way to conceive divine transcendence and immanence?

The challenge is to conceive of what has been called the 'causal joint' between mind and body, between divine action (e.g., calling) and human action (e.g., response). Does supervenience resolve or does it merely illustrate the problem? In particular, can one affirm the supervenience of the mental on the physical and speak of the mind as initiating mental and physical effects? In short, can one preserve the efficacy of the supervenient domain (the mind, God, the internal call) as opposed to that of the subvenient (the body, world, the external call)? In the contemporary philosophical discussion, the notion of a mental cause is a hotly disputed issue.

\section{A brief typology of positions}

The traditional position on the mind/body relation-Cartesian dualism - bears an uncanny resemblance to classical theism's view of the God/world relation. What we have in both cases is a picture of two separate realms composed of two kinds of reality that nevertheless interact. Both cases, that is, present us with the problem of the so-called 'causal joint'. Just what goes on in the pineal gland, the place where Descartes believed that mind and body meet? How is it that I form a decision to lift my finger and bring about the lifting of my finger? A similar problem holds for the relation of God and the world. Is there a theological equivalent to the pineal gland-the locus where the divine and human come into contact-perhaps the preaching of

57Ibid., 518. Demarest says that the single call of God to salvation 'may be considered from two perspectives': the external, evangelical call and the internal, effectual call (Demarest, The Cross and Salvation, 218). I shall later relate this to the position of 'anomalous monism' in the mind/body discussion. 
the word or the administering of the sacraments (or alternately the Incarnation)? The point is that, according to classical theism, there is a fundamental dualism between Creator and creation, grace and nature. The causal joint must therefore span an ontological gap. To the extent that this is so, the effectual call resembles something of an intervention, where one kind of reality enters into another kind of reality to produce an effect that would otherwise not have come about. Saving grace, on this view, is necessarily intervenient. 58

At the other extreme of the mind/body debate are the epiphenomenalists who argue that mental causation is only apparent. The real causal work, they maintain, is carried out by material brain processes. Instead of supervenience relations, this position posits systematic identities between the mental and the physical. The net result is an ontological reductionism that recognises the reality of the physical (or rather, the microphysical) only. 59

Modern science has been a major factor in how theologians and others have revised their conception of the God/world relation. How can we conceive of the God of the gaps when the gaps are few and far between? How can we

58Under Cartesian dualism, there can be no complete physical theory of physical phenomena, because the physical domain is open to influence form the mental. 'We can say then that Cartesian interactionism violates the causal closure of the physical domain' (Kim, Supervenience and Mind, 336). Precisely the same complaint is directed against the idea of divine causality. Moltmann warns that when definitions are derived from separation rather than relation, the result is the domination of one term (body) by the other (soul). Descartes describes the mind/body relation 'as a one-sided relationship of domination and ownership' (Moltmann, God in Creation, 251). The tendency 'to spiritualise the human subject and to instrumentalise the human body' parallels the tendency to see God as over the world, controlling it through causal interventions. Even Barth saw the ordered unity of the soul/body relation in terms of superordination and subordination ( $c f$. supervenience and subvenience). Peacocke raises another problem with this picture: its view of nature as a closed mechanical system controlled by 'laws of nature' is outdated. For Peacocke's criticisms of the concept of divine intervention, see his Theology for a Scientific Age, 141-43).

${ }^{59}$ Reductivists suggest that the way we normally speak of the mental (in terms of thoughts, decisions, and intentions) will eventually be left behind, replaced by a successful brain science. 
prevent the notion of the 'mighty acts' of God from sounding quaint or becoming outmoded? The theological counterpart of mind/body epiphenomenalism is a non-realist position like Don Cupitt's. God just is what happens between loving people. God-talk, that is, can be reduced to talk about human beings. It is therefore inappropriate to speak of divine causality, as it would be inappropriate to await divine help. The effectual call would on this view be explained in terms of conscience, or more radically, in terms of the sociobiological urge, say, to belong. Whereas for Feuerbach the secret of religion was atheism, for the epiphenomalist the secret of mind is physicalism. 60

We come now to the panentheistic analogy, poised somewhere between the theistic and atheistic options we have just considered. On this third view, it is not enough simply to affirm the causal joint-that God acts in the world, that the mind is distinct from the body. For without some plausible account of how God/mind might interact with the causal nexus of physical events, we cannot with integrity assert that there is such interaction. 61

Panentheism is a holistic worldview in the sense 'that it recognises that whole systems and their parts mutually condition one another' ${ }^{\prime} 2$ Each science analyses not a different kind but a different level of reality, each with its own irreducible integrity. Theology is the science that deals with reality at its

\footnotetext{
${ }^{60} \mathrm{Kim}$ notes that for Jonathan Edwards, the situation is precisely reversed: God's creative activity is the real cause of things and the causal relations obtaining between material bodies are cases of epiphenomenal causation. Fire does not cause smoke; rather, God causes the fire and then God causes the smoke (Kim, 'Epiphenomenal and supervenient causation', Supervenience and Mind, 92)

${ }^{61} \mathrm{Cf}$. Peacocke: 'The mere assertion of the analogy to human action without any further explication of it, and so also analogically of divine action, leaves us still sceptical of the mere possibility of the latter' (Theology for a Scientific Age, 150).

${ }^{62} \mathrm{~N}$. Murphy, Beyond Liberalism and Fundamentalism: How Modern and Postmodern Philosophy Set the Theological Agenda(Valley Forge, PA: Trinity Press International, 1996) 44.
} 
most all-encompassing level. 63 In the words of Nancey Murphy, theology is the supervenient discipline par excellence. ${ }^{64}$

With regard to the mind/body analogy, most of those who say that the mental supervenes on the physical are nonreductive physicalists. That is, they are naturalists who believe that nature is a hierarchy of complex systems whose higher levels are irreducible to lower ones. 65 Though non-reductive physicalists believe that the world is fundamentally physical (made up of physical entities and governed by physical laws) they reject reductive materialism for having an overly atomistic and mechanical view of these processes: 'The ontological imagination was stultified at the start by [the picture] of microscopic billiard balls. ${ }^{\prime} 6$

Non-reductive physicalism recognises that something genuinely new is going on at the level of the mind that cannot be explained simply in terms of brain activity.67 This is not quite proof for the existence of the soul. On the contrary, nonreductive physicalists would argue that there need be no spiritual 'thing' (no hypostasis) that 'has' mental properties. Nevertheless, some argue for the reality of the mental on the grounds that this yields greater explanatory power of the data than rival theories. 68

${ }^{63}$ As Murphy explains, this is not necessarily to say that theology is merely the science of the whole cosmos, but rather 'that the behaviour of the created universe cannot be explained apart from its relation to an additional kind of reality, namely, God' (Beyond Liberalism, 149)

${ }^{64}$ Murphy: 'As a supervenient discipline, theology can answer questions that arise within science but cannot be answered by science alone' (Beyond Liberalism, 156).

${ }^{65}$ For a brief history of non-reductive physicalism, see N. Murphy, AngloAmerican Postmodernity: Philosophical Perspectives on Science, Religion, and Ethics (Boulder, CO: Westview Press, 1997) 94-96.

66R.W. Sellars, cited in Murphy, Anglo-American Postmodernity, 195. Interestingly, classical theism could perhaps be accused of something similar, at least with regard to its view of the world

${ }^{67}$ 'For both the nonreductive physicalist and the emergentist, physical bases are by themselves sufficient for the appearance of the higher-level properties' (Kim, 'The nonreductivist's trouble with mental causation', Supervenience and Mind, 347).

${ }^{68}$ 'Against the opponents of mental causation, I argue that as long as the explanatory power of idea-idea causation continues to be much greater than the neurophysiological account, we should straightforwardly assert 
Donald Davidson, in his much-discussed paper 'Mental Events', claims that while mental events are identical to physical events, mental properties are dependent on the concepts we employ in describing those events. This is a subtle, but important, point: the non-reductive physicalist does not postulate a second kind of reality (the soul) as the subject of mental properties, 'but rather attributes mental and spiritual properties to the entire person, understood as a complex physical and social organism' ${ }^{69}$ Neither the mental nor the spiritual are illusory; neither philosophising nor praying can be reduced to brain matter in motion! Davidson further claims that there are no lawlike correlations between these mental concepts (e.g., intention, reason) and the concepts we use to describe physical events (e.g., mass, force). Science is unable to formulate laws that could explain the mental in terms of the physical. He is thus unwilling to reduce the mental to the physical, though at the same time, on the level of ontology, he rejects dualism. He chooses to call his hybrid position 'anomalous monism'. The main objection to Davidson's argument is that it seems to make the mental causally inert. For it is one thing to describe an event with mental concepts, quite another to say that it is the mental aspect which is causally efficacious. ${ }^{70}$

There is an interesting parallel between anomalous monism and God's call: 'Reformed theologians often speak of the gospel call and the effectual call as two aspects or sides of

its superiority and indispensability' (Clayton, God and Contemporary Science, 255).

69Murphy, Beyond Liberalism, 150.

${ }^{70} \mathrm{~F}$. Dretske gives an example of a soprano who sings meaningful words when she hits the glass-shattering high C: the meaning is irrelevant to the properties of the sound waves that cause the glass to shatter: 'The fear concerning mental causation is that all content-properties [e.g., desires, beliefs] may be like those of the soprano's high $C^{\prime}$ (L.R. Baker, 'Metaphysics and Mental Causation', in J. Heil and A.R. Mele (eds.), Mental Causation [Oxford: Clarendon, 1993] 76). The discussion in the journals is too technical to pursue much further here, other than to note a few salient points: R. Audi helpfully proposes that we see mental causes as sustaining causes which, though they may not trigger events, dispose agents to act in certain ways. This puts an interesting new spin on being in a 'state of grace' 
one calling. ${ }^{71}$ The effectual call is dependent on the evangelical call but cannot be reduced to it. Does this mean that the effectual call supervenes on the external call, that God's Word supervenes on the human word? One difficulty with this suggestion is the co-variation thesis: no A-differences without B-differences. If the required physical bases are present, the mental events that supervene on them must also be present. With regard to God's call, however, there is an obvious objection: Reformed theologians deny that the preached word works ex opere operato. To stipulate that God must always be salvifically at work wherever there is preaching is effectively to deny the freedom of God. We would then have to rewrite dominical wisdom: 'Many are called and just that many are chosen. ${ }^{72}$

Jaegwon Kim, whom I have already acknowledged as one of the leading specialists on the concept of supervenience, himself has serious doubts about the applicability of the concept to the notion of mental causation. Essentially, he believes that all instances of 'macrocausation' are epiphenomenal, ultimately explicable in terms of microcausal, that is microphysical, relations. ${ }^{73} \mathrm{Kim}$ sees the claim that psychological properties are irreducible to their subvenient properties as the remnants of a dualist ideology. His verdict is:

71Hoekema, Saved by Grace, 88. Bavinck writes: 'It is one and the same word which God allows to be proclaimed through the external call and which he writes on the hearts of the hearers through the Holy Spirit in the internal call' (cited in Hoekema, Saved by Grace, 89). The human person is now commonly seen as a psychosomatic unity with dual aspects.

${ }^{72}$ To escape the Kim's reductionistic conclusions, some point out that mental properties are 'multiply realisable'. That is, the same mental property may be realised by or supervene on different physical events. Kim rebuts this move by arguing that in the absence of some physical realisation, the mental property would not be there. He also defends the principle of 'explanatory exclusion', which states that there can be no more than one complete and independent explanation for any single explanandum (Supervenience and Mind, xiii).

${ }^{73}$ The trouble is that it is difficult to capture the dependence relation in a way that escapes the threat of reductionism. Since every property of every event supervenes on microphysical events and properties, it is hard to see how any macrophysical properties are causally relevant to anything. 
'Nonreductive physicalism, like Cartesianism, founders on the rock of mental causation. ${ }^{74}$

How can a non-physical event (e.g., a thought, a call) causally influence the course of physical processes? Earlier generations assumed that causation was always bottom-up, that is, that the basic forces of nature were described by the Newtonian laws of physics. On this view, God had to be thought of as a mover, as a quasi-mechanical force that enters into the causal nexus from outside and initiates change. 75 Supervenience, at least in Kim's hands, continues to assume bottom-up causation. In Kim's universe, macro-causation reduces to micro-causation. However, what many of us want to say-what perhaps we have to say unless we wish to go madis that consciousness makes a real difference in the world. Indeed, a number of thinkers believe that it is tantamount to intellectual suicide to deny the efficacy of macro-causation. ${ }^{76}$ What is needed is a notion of nonreducible supervenient causation. 77

If to be real is to have causal powers, what is the true causal story? What really moves the natural world, the human will? Human beings live on the level of macrocausation. True, many properties in chemistry and other sciences supervene on more basic properties. Yet who would deny that temperature, magnetism, and the like have their own explanatory, even

${ }^{74} \mathrm{Kim}$, Supervenience and Mind, 339.

${ }^{75}$ Murphy herself believes that we should emphasise God's involvement at the quantum level, where we can conceive of divine action in terms that need not conflict with science. See her 'Divine Action in the Natural Order: Buridan's Ass and Schrödinger's Cat', in R.J. Russell and A. Peacocke, Chaos and Complexity: Scientific Perspectives on Divine Action (Vatican City State and Berkeley: Vatican Observatory and Centre for Theology and the Natural Sciences, 1995) 325-57. However, Clayton objects that such a conception of divine action is really a conception from the very bottom-up, which, while possible, is not very plausible: there neither is, nor could be, empirical evidence for it.

${ }^{76} \mathrm{C}$. L.R. Baker: 'The conclusion that macro-properties lack causal efficacy is cognitively devastating' ('Metaphysics and Mental Causation', 90).

77See B. Enç, 'Nonreducible Supervenient Causation', in Supervenience: New Essays, 169-86. 
causal, power?78 Why, then, should the same not go for mental and spiritual properties too? Could we not say that 'causes are the sorts of things that are cited in explanations of events'?79 By and large, we explain our own actions, for instance, in terms of motives, desires, and reasons rather than in terms of microphysics and brain chemistry. So does the biblical narrative, even when it invokes divine agency. As we have seen, however, others invoke the concept of supervenience to subvert the reality of macrocausation: "what midsized slow philosophers see is not always a key to the mysteries of ontology.' 80 The same suspicion doubtless applies to midsized readers of the Bible.

Arthur Peacocke, a panentheist, suggests that the way in which God influences the world is analogous to the way in which the mind influences the body, which in turns is analogous to the way in which a whole influences its parts. ${ }^{81}$ Peacocke contends that some systems have causal power over their component parts. Think, for instance, of the way an ecosystem influences an organism: an animal's environment, through natural selection, can over time affect a species' DNA. Downward causation (also called 'top-down', 'whole-part', or 'supervenient' causation) opens the possibility of talking about divine action in non-interventionist terms, for on Peacocke's view, divine action is not like that of an object operating on the level of other objects, but rather at the level of the whole.

Peacocke helps us see why panentheism and supervenience are such compatible concepts. Panentheism says that the world is in God but God is greater than the world; supervenient or downwards causation suggests that God acts on the world, but only at the level of the whole, as its overarching context: "If God interacts with the "world" at this supervenient level of totality, then he could be causatively effective in a "top-down" manner without abrogating the laws

\footnotetext{
${ }^{78}$ According to T. Burge, 'Outside our philosophical studies, we all know that epiphenomenalism is not true' ('Mind-Body Causation and Explanation', in Heil and Mele, Mental Causation, 118).

79Baker, 'Metaphysics and Mental Causation', 93.

${ }^{80}$ Cited in Enç, 'Nonreducible Supervenient Causation', 175.

81Peacocke, Theology for a Scientific Age, 161.
} 
and regularities...that operate at the myriad sub-levels of existence.'82 In short, God's activity supervenes on the processes of nature themselves.

Brad Kallenberg suggests that God's action in the human world is similarly located at the level of the whole, namely, the community of which individuals are parts. ${ }^{83}$ And, as with other levels of reality, 'real properties emerge at this level of [social] complexity which cannot be accounted for by attention to phenomena concerning individual human beings in isolation'.84 Kallenberg's point is that the 'mind of Christ' supervenes on the 'body of Christ': 'those individuals who step outside the..."church" miss those unique causal influences orchestrated by God within the Christian community.' 85 Outside the church, one will not benefit from God's 'mental causation'.

What's wrong with downward causation? It is difficult to see how the mind could be dependent upon the physical and yet at the same time exercise independent causal powers that affect the physical. Kim is reluctant to allow two distinct sufficient causes for the same event. To believe that the mind independently causes things is to espouse something like Austin Farrer's notion of double-agency. For Kim's part, he believes that all higher level processes are derivative from and grounded in fundamental physical processes. To say otherwise is to introduce another kind of causality into the natural order and thus to breach the causal closure of the physical domain. If

82Peacocke, Theology for a Scientific Age, 159. If the world is God's body, then the succession of the states of the world-as-a-whole is also a succession in the thought of God. On the other hand, Murphy locates the causal joint between God and the world at the level of quantum physics. At the quantum level, nature itself is indeterminate. In the light of the butterfly effect, it is possible to think of God intervening at the microphysical level in order to bring about macrophysical changes (e.g., the parting of the Red Sea due to a kind of El Nino effect, or conversion due to the stimulation of neurons in the brain).

${ }^{83}$ Note that the community is one of the higher levels of reality which, like the others, has its own science and set of concepts (e.g., sociology, social theory, ideology, etc.).

${ }^{84}$ B.J. Kallenberg, 'Unstuck from Yale: Theological Method after Lindbeck', Scottish Journal of Theology 50 (1997) 210.

85Ibid., 214. 
one is willing to embrace 'higher powers' (e.g., psychic energies, souls, God), asks Kim, then why call yourselves a nonreductive physicalist? Why, for that matter, posit supervenience?

Does supervenience save the reality of mental causation? If not, it is difficult to see how the panentheist's mind/body analogy could illumine the nature of the God/world relation. We may need a concluding unscientific postscript on supervenience. Happily, something like this has recently been provided by Philip Clayton. Clayton believes that theology indeed has a stake in arguing for the irreducibility of consciousness, but in the final analysis the theologian must assert that God's 'mind' transcends the world and its processes. When it comes to the God/world relation, theological realists cannot be physicalists, even of the non-reductive variety. 86

Must we conclude that theology contradicts science? Not necessarily, for Clayton rightly points out that the results of science underdetermine one's choice of metaphysical interpretations. 87 Science provides the exegetical data concerning the Book of Nature, we might say, but metaphysics (and theology!) supply the hermeneutics. What Bultmann said of biblical scholars applies equally to scientists: exegesis without presuppositions is impossible. Physicalism is a metaphysical, not a scientific, thesis. The question of the God/world relationship is similarly underdetermined by science. 88

What of supervenience? Is it a scientific or a metaphysical concept? Its critics say that supervenience, failing a specific account of the dependence relation that underlies it, is 'simply an empty sound expressing a faith that two levels of properties are somehow related' ${ }^{89}$ While there does seem a sort of asymmetric relation between mind and body, why should

86If this means that God's causality cannot be explained in terms of thisworldly processes, then how does one ultimately avoid falling into some kind of dualism? Clayton's answer to this query is not entirely clear.

87Clayton, God and Contemporary Science, 259.

${ }^{88}$ Note that, for Clayton, the theological supplementation of science 'does bring panentheism more into the spirit of biblical theism' (260). God is not simply an emergent set of divine properties, but a being in his own right.

${ }^{89}$ Cited in Savellos and Yalçin, New Essays in Supervenience, 9 
the physical be thought of as more ontologically basic? Why should we accept the causal closure of the physical world?

\section{Prevenient and supervenient grace: from Pinnock to Peacocke}

Peacocke admits that his view allows for divine action only 'on the world as a whole'. This gets us no further than a 'general call'. Even Pinnock's emphasis on prevenient grace gets us no further. According to the free-will theist, God is working behind the scenes with every individual entity to draw each one to himself; according to the panentheist, God is exercising systemic influence on the world as a whole. Both prevenient and supervenient grace, it would appear, have universal application, prompting us to speak of continuous salvation. What, then, is the role of the Spirit in applying salvation?

On the traditional view, the Spirit is the one who imparts grace to believers. The infusion of grace resembles a transfer of energy. The Spirit, then, is indeed like a physical force. Better, God, as love, acts on individuals like a force field, empowering humans freely to respond.

Peacocke prefers to see top-down causation in terms of a transfer of information (another kind of 'glorious exchange') rather than in terms of energy. .0 God interacts with the world by inputting information-not by special revelation (too interventionist) but by 'programming' natural processes, though their in-built propensities, progressively to realise his intentions. 91 God communicates his intentions through 'patterns of meaning' within the evolutionary history of the natural world. Hence we are to see God's intentions manifested in, say, the emergence of human beings from lower forms of life. On this view, the Spirit is more like the operating system,

90Peacocke attributes J. Bowker's The Sense of God (Oxford: Clarendon, 1973) with being the first work to see divine action in terms of 'information input'.

${ }^{91}$ Indeed, the distinction between 'natural' and 'revealed' theology is too dualist for Peacocke. He would prefer, I think, to say that revelation supervenes on universal history. 
or software, of creation. In sum, God communicates to humanity through the fabric of the natural world.92

Peacocke's account of the Incarnation, however, leads us to wonder whether supervenience ultimately fails to get us beyond a qualified deism. In the final analysis, God acts only on 'the world-as-a-whole' ${ }^{93}$ The Incarnation, for Peacocke, is not a matter of God entering a closed causal nexus from the outside as a stranger, but rather of certain divine properties emerging in the man Jesus from within the natural processes of creation. 94 Jesus, says Peacocke, was a totally God-informed man, the 'ultimate emergent'. 95 The Incarnation, therefore, is not so much a miracle as it is a particularly pure case of how the information God inputs into creation results, through an evolutionary process, in the embodiment of God's intentions:

The 'Incarnation' in Jesus the Christ may, then, properly be said to be the consummation of the creative and creating evolutionary process. It would follow that, if Jesus the Christ

92Peacocke admits that it is difficult to say how God inputs information into the world-as-a-whole without an input of matter/energy: 'This seems to me to be the ultimate level of the "causal joint" conundrum' (Theology for a Scientific Age, 164). For a more explicitly Trinitarian version of panentheism, see Moltmann's God in Creation. Many themes in Moltmann are relevant to the present essay, though beyond its scope. Moltmann views the world as a dynamic relation of open systems in which higher levels have higher capacities for communication (204). In his view, 'spirit' names the forms of organisation and modes of communication in open systems (263). Moltmann reconceives the body/soul relation in terms of his theology of Trinitarian perichoresis (259). Life is exchange: communication and communion. Life, or spirit, is what happens between individuals (266). Though we cannot examine it here, it may be that, for Moltmann, the Holy Spirit supervenes on the Creator Spirit.

93Peacocke, Theology for a Scientific Age, 163.

${ }^{94}$ Peacocke understands Incarnation 'as exemplifying that emergencefrom-continuity which characterises the whole process of God's creating' ('The Incarnation of the Informing Self-Expressive Word of God', in W.M. Richardson and W.J. Wildman (eds.), Religion and Science: History, Method, Dialogue [New York and London: Routledge, 1996] 331). Note the similarity with M. Wiles's notion that creation is God's single 'master act', with persons like Jesus Christ, presumably, being the culmination of the creative process.

95So Clayton, God and Contemporary Science, 225; cf. Peacocke, 'Incarnation', 332. 
is the self-expression of God's meaning, then the evoking in the world of this kind of person, with these values, just is the purpose of God in creation. 96

Peacocke's mention of God's evoking brings us back to the notion of the effectual call: for him, God's call operates on the world as a whole to produce people like Jesus. The question is whether such a view is adequate for Christian faith. Is it possible to have a personal relation with one whose presence and activity is always only prevenient or supervenient?

\section{Divine communicative action and 'advenient' grace}

Nicholas Wolterstorff, in his Divine Discourse, offers a stimulating series of philosophical reflections on the claim that 'God speaks'. 97 I propose to offer some theological reflections on this claim as well. The closing stages of this paper is hardly the place to propose a new picture of the God/world relationship, so what follows will necessarily be somewhat sketchy. In brief, I propose thinking of the God/world relation in terms of communicative rather than causal agency. The call exerts not brute but communicative force.

The challenge, we may recall, is to respond to the criticisms that theism is unbiblical, blasphemous, and unscientific. A secondary challenge is to account for the peculiar efficacy of God's call. The concept of the speech act enables us, I believe, to unpack the nature of the effectual call, and of God's overall relation to the world, in terms of both energy and information. Moreover, speech act theory sheds new light on certain themes from our earlier discussion: (1) how the effectual call can be regenerative; (2) how the effectual call can be internal and external; and (3) how the illumination of the Spirit relates to the illumination of the Word.

96Peacocke, Theology for a Scientific Age, 334.

${ }^{97}$ N. Wolterstorff, Divine Discourse (Cambridge: CUP, 1995). 


\section{Summoning: a sovereign speech act}

Speech acts belong to the twentieth-century philosophy of language. The main point is that in speaking, we also do certain things. Words do not simply label; sentences do not merely state. Rather, in using language we do any number of things: question, command, warn, request, curse, bless, and so forth. A speech act has two aspects: propositional content and illocutionary force, the 'matter' and 'energy' of communicative action. ${ }^{98}$ The key notion is that of illocution, which has to do not simply with locuting or uttering words, but with what we do in uttering words. We may distinguish, with Jürgen Habermas, speech acts from strategic acts; whereas the former aim to communicate, the latter aim only to manipulate. It is one thing to bring about a result in the world, quite another to bring about understanding. My claim is that God's effectual call is not a causal but a communicative act.

For Arminians, the New Testament language of calling is a matter of 'naming' those who have believed. It is thus declarative, not a directive; that is, it is a speech act such as a command, which aims to fit the world to the word. On the other hand, John Murray, commenting on Romans 8:30, equates the effectual call with a summons:

Salvation in actual possession takes its start from an efficacious summons on the part of God and this summons, since it is God's summons, carries in its bosom all of the operative efficacy by which it is made effective. ${ }^{99}$

'Summoning' is a much stronger directive than 'inviting'. It is significant that Jesus did not invite the disciples to tea, but rather said 'Follow me'. Augustine found the idea of an effectual call in other biblical examples. So, Jesus commands, 'Lazarus, come out' (Jn. 11:43), a speech act that literally wakes the dead. For Augustine, something similar happens each time God summons a person to new life. Not everyone can issue a felicitous summons, however; certain truth conditions are

98For a complete analysis, see J. Searle, Speech Acts: An Essay in the Philosophy of Language (Cambridge: CUP, 1969).

${ }^{99}$ Murray, Redemption Accomplished and Applied, 86. 
assumed, for instance, that I have the authority to summon you. Only God, of course, has the right to say certain things, for example, 'I declare you righteous'. 100

\section{The effectual call and the 'communicative joint'}

Is the grace that changes one's heart a matter of energy or information? I believe it is both, and speech act theory lets us see how. God's call is effectual precisely in bringing about a certain kind of understanding in and through the Word. The Word that summons has both propositional content (matter) and illocutionary force (energy).

We have seen that some who champion the notion of supervenience assign an independent causality (and hence reality) to mental properties. Their main argument, again, is 'that mental causation makes the best sense of the phenomena of human experience'. ${ }^{101}$ But what does mental causation really mean? How do ideas 'cause' other ideas? Does the idea of ' $2+$ 2 ', say, cause the idea of ' 4 '? Does Jesus' summoning his disciples cause them to follow?

Classical theism sees God as a mover. Causation is a transitive relation: $x$ pushes, pulls, heats, freezes, saves $y$. Communication is a transitive relation too ( $x$ addresses $y$ ) but is it causal? I have suggested that God is a communicative agent. While I agree with Kallenberg that language is an 'emergent property', I think we can say more than he does about how God supervenes at the social level. Humans are indeed 'ontologically constituted' by language, and this insight puts a wholly different spin on the question of how the effectual call works a change of the human heart. Moving beyond Kallenberg, why could we not see God as a member of the Christian linguistic community? After all, one of the most common biblical depictions of God is as a speaker. 'We speak because he first spoke us.'

The doctrine of the effectual call prompts us to change pictures and think not of a causal but of a communicative joint and to identify the point at which communication takes place as

100 On my view, justification (the next doctrine in the ordo salutis) is very much a divine speech act too.

${ }^{101}$ Clayton, God and Contemporary Science, 256. 
interpretation. The effectual call thus provides the vital clue as to how God interacts with the human world. In my opinion, the Reformers were right to stress the connection between God's Word and God's work of grace.

\section{Address and 'advenient grace'}

If we are to make sense of the communicative joint, however, we must explain what happens when the Word of God enters the world. Speech act philosophy helpfully provides a set of concepts with which to think about word events. For it is indeed the Word which comes to the world and the Spirit which comes to the Word that informs and empowers-in a word, that is effectual. Perhaps the most adequate way to view the God/world relation is in terms of advent.

It is clear that when the word of God comes, it brings about change. Acts 16:14 shows Lydia's regeneration taking place through Paul's gospel preaching. New human possibilities do indeed emerge, therefore, but not out of purely natural processes. Many emerge out of history, in particular out of communicative action, as Eberhard Jüngel recognises: 'The word is to be seen as the actual core of historical reality because it interrupts the natural context of existence in such a way that something like historical reality becomes possible.'102 The world, then, is not a hermetically closed system but one that is hermeneutically open. ${ }^{103}$ And the way this system is put into motion is through God's communicative, and selfcommunicative, action. 104

Yes, God 'bends and determines' the will, but even the seventeenth-century theologians knew that God 'moves the will to attend to the proof, truth and goodness of the word announced'. ${ }^{105}$ Divine communicative action is thus of a wholly

${ }^{102 \mathrm{E}}$. Jüngel, God as the Mystery of the World (Edinburgh: T. \& T. Clark, 1983) 189.

${ }^{103}$ 'It has to be understood as a system that is open-open for God and for his future' (Moltmann, God in Creation, 103).

${ }^{104}$ The philosopher G.H. von Wright argues that agency is the power to initiate change in a system. To affirm God as speaker is to assert that God puts language systems into motion (Explanation and Understanding [Ithaca, NY: Cornell University Press, 1971]).

105 Heppe, Reformed Dogmatics, 520. 
different sort than instrumental action, the kind of action appropriate if one were working on wood or stone. God's work of grace is congruous with human nature. 106

Jesus immediately qualifies his statement 'No one can come to me unless the Father...draws him' with a citation from Isaiah 54:13: 'And they shall all be taught by God.' On this he provides the following gloss: 'Every one who has heard and learned from the Father comes to me' (Jn. 6:45). The Father's drawing, in other words, is not causal but communicative. The word itself has a kind of force. One might say, then, with regard to grace, that the message is the medium.

I believe that certain concepts drawn from speech act philosophy help us better to understand what happens in a word event. Furthermore, I suspect that these same concepts may also aid in the construction of a model for the broader God/world relation. What we have in gospel preaching is a narrative illocution. What does one do in narrating? One displays a world and commends a way of viewing and evaluating it. 107 One literary critic describes the illocutionary force of narrative as 'ideological instruction'. 108 Stories not only provide information but cultural formation as well; they give training in ways of being human. Even secular stories can sometimes prick our conscience or provoke a radical change of lifestyle. How much more the Gospel narratives.

Jüngel observes that the event of addressing results in a concrete relation between the discourse, the subject of the discourse, and the one being addressed. Something happens in and through talk about God in Christ. What happens is that God comes to speech: 'God's humanity introduces itself into the

${ }^{106}$ God's Spirit does not violate human nature but 'acts in perfect consistency with the integrity of those laws of our free, rational, and moral nature, which he has himself constituted' (Hodge, Outlines of Theology, 452).

107See M.L. Pratt, Towards a Speech Act Theory of Literary Discourse (Bloomington: Indiana University Press, 1977).

${ }^{108}$ See S.S. Lanser, The Narrative Act: Point of View in Prose Fiction (Princeton: PUP, 1981). I discuss narrative illocutions in my Is There a Meaning in this Text? The Bible, the Reader and the Morality of Literary Knowledge (Grand Rapids: Zondervan, 1998) 341. 
world as a story to be told.' 109 Only through narrative, says Jüngel, can we articulate, and then actualise, certain 'emergent possibilities' for human being. Jüngel construes the God/world relation, in other words, as a story that alters the course of history. 'The hearer must be drawn existentially into this story through the word, precisely because it is also his story, and this must happen before he can do what corresponds to this story.' 110 For Jüngel, it is the Gospel narrative that effectually calls people to union with Christ by drawing them into the story of Jesus.

Does it follow that the effectual call supervenes on the preached word? No, for this proves too much. Not every one who hears is automatically united to Christ. Though there is a connection between the external and internal call, it is not supervenience. 111 As we saw earlier, anomalous monism holds that one can describe the same event with two sets of properties, but in the case of the effectual call the one (viz., external) does not always entail the other (viz., internal).

How, then, are we to understand the relation of the evangelical and the effectual call? If God deals with us communicatively in a manner that befits our nature, what is it about certain communicative acts that renders them efficacious? Could it be not merely the message, but its truth? Charles Finney believed that the preacher and the Spirit alike can do nothing more than present the truth. Aquinas believes, on the contrary, that the truth carries its own persuasive force. Just as we cannot help but assent to logical truths once we have understood them, so we cannot but be drawn to what we see as good. On the other hand, the truth in and of itself, often seems powerless to change us. Light alone does not enable the blind person to see. We need the illumination of the Spirit for that. Not for nothing has the Reformed tradition discussed the effectual call in terms of both Word and Spirit.

109Jüngel, God as Mystery, 302.

110 Ibid., 309.

$111 \mathrm{Or}$ perhaps it is, if we follow Murphy and stipulate that the supervenience relation also depends on the surrounding circumstances, which could of course include the Spirit's presence. 
The Spirit's work is to illumine not the truth, but the mind. One who has been illumined is both passive and active: being made to understand, one understands. 'Here we perceive the link between the efficiency of God and the activity of man.'112 But we must press further: in what does the effectuality of the Spirit precisely consist? What, if anything, does the Spirit add to the Word?

There is a connection, I submit, between pneumatology and perlocutions. To return to speech act theory: a perlocution is what one brings about by one's speech act. Speech frequently presents an argument, but arguments are intended to produce assent. Perlocutions have to do with the effect on the hearer of a speech act. 113 Now, the primary role of the Holy Spirit, I believe, is to minister the Word. The application of salvation is first and foremost a matter of applying both the propositional content and the illocutionary force of the Gospel in such a way as to bring about perlocutionary effects: effects which, in this case, include regeneration, understanding, and union with Christ. Not for nothing, then, does Paul describe the Word of God as the 'sword of the Spirit' (Eph. 6:17). It is not simply the impartation of information, nor the transfer of mechanical energy, but the impact of a total speech act (e.g., the message together with its communicative power) that is required for a summons to be efficacious. The Spirit, the 'Lord of the hearing' according to Karl Barth, is nothing less than the subjective reality of God's sovereignty. The effectual call is best understood in terms of a conjunction of Word and Spirit, illocution and perlocution.

Does the Spirit, then, supervene on the Word? I can give no more than a qualified 'Yes' to this query, for while the Spirit's call depends on the external call and is irreducible to it, it is nevertheless possible to have Gospel preaching without regeneration. 'Advene' would therefore be a more accurate term. For the Spirit comes to the Word when and where God

112Strong, Systematic Theology, 822.

${ }^{113}$ The illocution-what the speaker has done-is the objective aspect of the speech act; the perlocution-the intended effect of the act-is the subjective aspect of the speech act. 
wills. The Spirit 'advenes' on truth to make it efficacious.114 The best analogy I have yet come across of advenient grace comes from the autobiography of Helen Keller. Her problem-how someone blind and deaf could be brought to understand language-parallels that of the sinner, one whose mind is darkened and whose ears are closed to the call of God; and indeed, Helen Keller writes of her coming to understand in terms of a religious conversion. 115 When her teacher first came, she 'spelled' words into Helen's hand. Helen learned to imitate the finger movements that spelled various words, but she failed to understand that these movements were words. One day, her teacher spelled the word water into one of Helen's hands as she held the other under a spout, and the mystery of language was revealed. Helen later wrote: 'I knew then that ' $w$-a-t-e-r' meant the wonderful cool something that was flowing over my hand. The living word awakened my soul, gave it light, hope, joy, set it free!'116 Here is no impersonal physical force, but a wonderful example of how communicative acts can achieve a liberating effect. Helen's teacher, a miracle worker like the Holy Spirit, ministered the Word and brought about understanding.

${ }^{114}$ Representatives of the school of Saumur held that the Spirit illumines the mind in such a way that the will cannot fail to follow practical reason. There is no direct operation of the Spirit on the human will, only through the mediation of the intellect. Mainstream Reformers typically deny this: the Spirit operates directly on the human will as well. Berkhof states that the influence of the Spirit is not the same as the influence of truth. What we have here is a stand off between those who champion the 'information' of the Word and those who privilege the 'energy' of the Spirit. We can perhaps side-step this criticism (that the Spirit's role is considered merely epistemic, that the Word is directed to the mind and not to the will) by observing (1) that speech acts involve more than propositional content and intellectual assent, (2) epistemology is itself indebted in various ways to ethics, and (3) that the speech act of summoning involves both propositional content and illocutionary force, that is, both Word and Spirit. For six arguments showing that there is an immediate influence of the Spirit on the soul, besides that which is exerted through the truth, see Strong, Outlines of Theology, 451.

${ }^{115}$ The film of her life is entitled 'The Miracle Worker', a reference to her teacher, who I suppose is the counterpart of the Holy Spirit inasmuch as it was she who efficaciously ministered the word to Helen and brought about understanding.

${ }^{116}$ Helen Keller, The Story of my Life (New York: Signet, 1988) 18. 


\section{Conclusion: communicative agency and the sovereignty of God}

\section{God the speaker}

What type of systematic theology am I advocating? The ontological, panentheistic type that views God as supervening on the world, or the cosmological, supernatural type that views God as a stranger to our world? In fact, I have followed neither of these paths, preferring rather a communicative theism in which God is a sovereign speaker: locutor, illocution, and perlocution. What God says makes a difference, but it would be perverse to describe this difference in terms of impersonal causation. If God's call must be described in terms of causality, it would have to be of a communicative kind, and hence personal. God comes to the world in, and as, word. To be precise, God relates to the world with both 'hands': Word and Spirit.

\section{Sovereignty and supervenience}

There is a prima facie tension between sovereignty and supervenience, best seen in the divergent ways in which theists and panentheists interpret saving grace. Supervenient grace is ultimately sacramental, for it is the cosmos rather than the Christian canon that mediates God, mediates whatever it is that makes Jesus 'Christ'.117 A consistently panentheistic theology must assert that it is the world as a whole that represents God's general (though only partially effective) communicative intent.

For the theist, however, all of God's communicative actions originate from his free love. The Word of God is God's gracious communicative, and self-communicative, act. Nothing in the world, whether in its microphysical or its macrophysical dimension, can constrain God's Word or force God to speak. While perlocutions do 'emerge' from illocutionary acts, they do not do so necessarily. To say that the internal call necessarily accompanies the external call would be to compromise God's freedom. In the strict or 'strong' sense of supervenience, there is

117 So Peacocke, who sees the cosmos as a kind of sacrament (Theology for a Scientific Age, 192). 
little scope for divine sovereignty. In sum, it is theologically incorrect to say that the effectual call supervenes on the evangelical call.

\section{Classical and communicative theism}

Finally, it must be asked: Have I relied, in my exposition of the effectual call, on 'a form not taken from the thing itself but from contemporary philosophies' (Barth's worry about seventeenthcentury theology)? No, for the 'thing itself' (the effectual call, God's salvific relation to the world) takes the form of a communicative act: Jesus Christ, the Word of God made flesh.

God's transcendence and immanence can be helpfully thought of in terms of communicative agency. God's transcendence is a matter of his being able to initiate and complete communicative action. Yet the distance between God and the world-from our side an infinite qualitative distanceis a distance that can be traversed via communicative action. God's self-communication is 'advenient'. Jesus came unto his own, though the world knew him not. It follows that the advent of God's Word is not a foreign intervention. On the contrary, if God is a stranger it is only because humanity has turned its back and made him so.

I have argued that the doctrine of the effectual call resists both the classical theistic picture of God's efficient causality and the contemporary panentheistic picture of God's supervenient causality. This doctrine rather leads us to rethink the God/world relation itself. I have suggested that one fruitful way forward for systematic theology is to conceive of God as a communicative agent. The effectual call (together with the Incarnation) then becomes the paradigm for how God is related to the world more generally. The next step, and one that must be postponed for an occasion other than this, would then be to rethink other central Christian doctrines (e.g., creation, providence, justification, the Trinity) in terms of God's communicative action. ${ }^{118}$

118Ultimately, what God wishes to communicate is himself. As we have seen, the effectual call ushers us into union with Christ, and thence into fellowship with the triune God. 